\title{
Private Forest Owners and the Forest Resource Database
}

\author{
Koji Matsushita*1 and Shigejiro Yoshida*2
}

\begin{abstract}
This paper investigated private forest owners' awareness of the forest resource database, Shinrinbo. The database is used to develop forestry plans and track forestry statistics. There are many discrepancies between the values shown in the database and the actual stands. To clarify forest owners' opinions on the Shinrinbo and related forest information systems, a questionnaire was conducted in Ousumi Regional Forest Planning Area in Kagoshima Prefecture in July 1996 and useful responses were obtained from 793 forest owners. It was found that : (1) $17.9 \%$ of forest owners were not aware of Shinrinbo itself. $60.2 \%$ were only aware of the name of Shinrinbo but did not know the contents. Only $15.4 \%$ indicated that they understood the contents of Shinrinbo. (2) $23.8 \%$ of forest owners knew that at least some part of the Shinrinbo data on their forests was wrong. The actual percentage of errors is probably greater, especially for area. Also, the database uses a simple yield table for data estimated before 1970 , as the constant table. (3) $18.4 \%$ of forest owners clearly indicated a willingness to supply correct information on their forests to the prefectural government. (4) Most forest owners think that the prefectural government, currently managing the Shinrinbo, is not the appropriate organization to manage a forest resources database. The most appropriate manager was thought to be the local forest owners association $(70.2 \%)$. The role of local forest owners association in private forest practices and local forestry development policy has been increasing, and forest owners' expectation that local forest owners associations should play a role building a database is also high.

As there are many small-scale forest owners in Japan, cooperation between owners to develop an accurate forest resource database is extremely important, especially as the role and social expectations of a database are increasing. However, forest owners' awareness of the Shinrinbo is low and awareness of the private Forest Operation Plan even lower. Approximately $90 \%$ of forest owners are formally involved in the Forest Operation Plan and obtain several benefits under related laws, for example subsidies and tax reduction, but only $20.6 \%$ of forest owners answered that they have a Forest Operation Plan. This suggests that forest owners do not adequately participate in forest planning process. An extension program for forest owners is discussed and improvements suggested for the information system and the method of forest inventory.
\end{abstract}

Keyword : private forest owner, forest resource database, Shinrinbo, forest information system, forest planning system

\section{INTRODUCTION}

The importance of databases in all kinds of economic and non-economic activities has grown. This also applies

${ }^{* 1}$ Division of Forest Science, Graduate School of Agriculture, Kyoto University Kitashirakawa-Oiwake-Cho, Sakyo-ku, Kyoto, 606-8502, Japan

${ }^{* 2}$ Department of Forestry, Faculty of Agriculture, Kyushu University 6-10-1 Hakozaki, Higashi-ku, Fukuoka, 812-8581, Japan to forest management in Japan. The database of nonnational forests in Japan is called the Shinrinbo, and is the source of basic statistics on forestry and forest resources in non-national forests. Non-national forests comprise $58 \%$ of the total forest area and $65 \%$ of the total standing volume in Japan. The Forestry Agency of the Government of Japan determined the contents of the current Shinrinbo, under Article 8 of the Regulation on the Regional Forest Plan of non-national forests and Regional Forest Plan of National Forests (Ministry of Agriculture, Forestry and Fisheries, Order No.20 of 1991 ; hereafter, Regulation on the Regional Forest Plan). Forty-seven prefectural govern- 
Table 1 Contents of the Shinrinbo

\begin{tabular}{|c|c|}
\hline Category & Explanations \\
\hline Administrative area & Forest planning area, Municipalities, District forestry office \\
\hline Location of forest & Compartment, Sub-compartment, Section of village, Lot number \\
\hline Forest owner & Name, Classification whether living in the village or not \\
\hline Type of function & $\begin{array}{l}\text { Timber production, Water conservation, Mountain conservation } \\
\text { Living environmental conservation, Recreation and culture }\end{array}$ \\
\hline Type of forest & Protection forest, Natural park system \\
\hline Area & Unit: ha (to the second decimal place) \\
\hline Classification of forest & By forest management type and story \\
\hline Forest type & Artificial forest, Natural forest, Cutover land, Treeless, Bamboo \\
\hline Detailed type & $\begin{array}{l}\text { Single storied forest, Multi-storied forest, Improved natural } \\
\text { forest, Naturally regenerated forest }\end{array}$ \\
\hline Story & Classification by upper story and lower story \\
\hline Species & Species code, Current and future \\
\hline Ratio of mixed & Percentage in volume base \\
\hline Ratio of area & By story in case of multi-storied forest \\
\hline Age & Average and range of age in uneven-aged forest \\
\hline Age class & One age class is 5 years interval \\
\hline Crown density & 3 classifications (sparse, medium and dense) \\
\hline Site quality & For main species, Current and future \\
\hline Locality & Current and future \\
\hline Site class & For main species, Current and future \\
\hline Method of cutting & Clear cutting, Selective cutting, Felling prohibition, Others \\
\hline Method of regeneration & Plantation, Natural seedling, Sprouting, Difficult to regenerate \\
\hline Improvement of forest type & Single storied forest, Improved natural forest management \\
\hline Specific management area & $\begin{array}{l}\text { Multi-storied forest, Long rotation management } \\
\text { Forest specified method, Forest for promote to cut }\end{array}$ \\
\hline Volume & Volume per ha, Unit: $\mathrm{m}^{3}$, By coniferous and broad-leaf \\
\hline Growth & Growth per ha, Unit: $\mathrm{m}^{3}$, Total growth \\
\hline Volume at the cutting age & Volume per ha, Unit: $\mathrm{m}^{3}$ \\
\hline Forest management plan & Presence of authorized forest management plan \\
\hline Profit-sharing forest & Type of profit-sharing reforestation \\
\hline $\begin{array}{l}\text { Recreation forest } \\
\text { Remarks column }\end{array}$ & Recreational forest, Public health forest \\
\hline
\end{tabular}

Source: Shinrin Keikaku Seido Kenkyukai (1992) pp.96-107.

ments each created databases containing the basic items determined by the Forestry Agency, and continue to manage these databases. The items recorded in each prefectural system are almost the same because the basic contents were already specified. The basic items are shown in Table 1. For national forests managed directly by the Forestry Agency, there is another database which contains less information than the database on non-national forests. Data is recorded for each forest owner and tree stand. Most statistics used for forest resource planning derived by summing the data in the Shinrinbo. This type of forest data system is unique to Japan, and Continuous Forest Inventory, which is the usual method in other developed countries, is not practiced in Japan (NISHIKawa, 1994).

Article 15 of the Regulation on the Regional Forest
Plan states that the regional forest plan and related maps should be open to the public, but there are no articles specifying public access to the related database, the Shinrinbo. Most of the data in Shinrinbo relates to private property. The database has been used to set public policy by the Department of Forestry particularly at the prefectural level.

Recently, uses for the database have increased. These include needs in the public sector outside the department of forestry. A typical example is the environmental database system. The importance of environmental policy in Japan has been increasing and a database on the environment is now required. The forest resource is a highly important environmental resource but the Environment Agency has no national-level database on it. In forestry research, an 
attempt at forest resource accounting including environmental aspects has begun (KorKe et al., 1997 ; Ү АмAмото, 1997), and accurate figures are needed. Another example is the increasing need for information by other forest interests, such as, local forest owners associations. Under the most recent Amendment to the Forest Law (1991), the regional forest planning area, which is the basic unit of forestry development, has become a watershed area. Establishment of forest information centers is being discussed in each forest planning area. Recently, personal computers have become capable of coping with the large amount of data which gives greater access to the Shinrinbo. For example, Yoshida (1986) described renewal of the data in Shinrinbo using a personal computer in Kumamoto Prefecture and KомAKI (1988) described the use of computers to develop a Shinrinbo management system for the forest owners association in Iwate Prefecture. There are many such examples. A third example of the increased need for a forest database is the development of geographical information systems (GIS). For example, Gifu Prefecture, one of the most active prefectures in the field of forestry information systems, introduced GIS, and YоNEMOTo et al. (1994) pointed out that accurate data is needed to improve the system. Makino et al. (1994) tried to develop a GIS system for introducing highly efficient forestry machines in Fukui Prefecture. Lastly, usage of database such as Shinrinbo is also developing in research. TATsuHARA (1994), for example, proposed a method of predicting the growth of coniferous plantations using information from the Shinrinbo.

If the use of Shinrinbo is to increase, the accuracy of the database must be examined, because the extent to which the data can be used depends on its accuracy. If the database described in Table 1 was based completely on real stands, it would be very useful. However, there are many discrepancies between the figures in the database and the real situation, and therefore the database is not very reliable. A new national-level forest inventory system is now being developed by the Forestry Agency, and the improvement of the Shinrinbo is also being considered (ShIRAISHI, 1995). The current data management system has many problems particularly in the data structure and information systems. The contents of the Shinrinbo are also being reconsidered, for example, the kinds of broad-leaved trees included and the accuracy and precision of the yield tables. These are important consideration in updating and improving the database, but I also suggest that another important cause of the problems in the current system is related to forest owners.

Article 21 of the Regulations on the Regional Forest Plan specifies that the Shinrinbo and related maps must be maintained in the local offices of prefectural governments. The Shinrinbo can also be stored in municipal offices, particularly those which have a forest improvement plan.
Thus the Shinrinbo is both managed and used by prefectural governments and municipal offices, rather than by the forest owners. In order to develop a national forest database and ensure effective utilization of the existing system, the accuracy of the Shinrinbo must first be improved. In this paper, we consider the importance of the relationship between Shinrinbo and forest owners in this process.

There are four important points in the relationship between the Shinrinbo and forest owners which affect its utilization. Firstly, the cooperation of owners is essential if any system is to be effective. This applies to every project involving privately owned forests, and is an important factor if the non-national forest resource database is to be improved. Secondly, the importance of consensus among those involved in planning forest resource utilization has recently been recognized, and clearly this must include forest owners. An accurate Shinrinbo can provide a common database for making decisions about forest use. Thirdly, statistical projects have generally deteriorated in Japan. Limited budgets have reduced the number of survey staff in central and local governments. Prefectural governments' local agriculture and forestry offices are unlikely to have any additional resources for survey projects in the future, so it is vital to have the cooperation of the forest owners. Lastly, a regional forestry activation program has recently begun, and a forestry information system that includes cutting activities (final cutting and thinning) is required for future business. Generally, post-war forestry policy has been one of land management and the related planning and data management systems have strictly related to these policy areas. However, cutting activity is now related to sustainable regional forestry, and forest owners can contribute to this information system. These four points must be considered and the relationship between the Shinrinbo and forest owners clarified.

This paper examines the attitude of forest owners to the database, using results from a questionnaire undertaken in Ousumi Regional Forest Planning Area in Kagoshima Prefecture in the southern Kyushu. In particular, the forest owners' concern regarding the system and their cooperation with the system, as well as the relationship between forest owners and the forest database are discus. sed. Finally, several policy implications are identified.

\section{QUESTIONNAIRE AND SUMMARY OF FOREST OWNERS}

As part of the regional forest labor study program subsidized by the Ministry of Labor of the Government of Japan, a survey of private forest owners who are representative members of local forest owners associations in Ousumi Regional Forest Planning Area was undertaken to investigate the regional situation with respect to forest 
resources, forest management and forest products supply. A questionnaire was sent to 1,350 forest owners on July 24, 1996 and 825 replies were received by August 30 (response rate of $61.1 \%)$. Overall, $793(58.7 \%)$ responses were analyzed in this paper. The planning area consists of 210 thausand ha, $63.0 \%, 13.4 \%$ and $3.4 \%$ of which are forest, agricultural land and residential lands, respectively. The forest area covered by the Forest Law consists of 123,528 ha, $38.8 \%$ of which is national forest and $61.2 \%$ of which is public and private forest. The proportion of needleleaved trees in the total forest resource is $68.6 \%$ in area and $77.7 \%$ in standing volume. Artificial forests comprise $69.0 \%$ of the non-national forests, the major species of which are Cryptomeria japonica (sugi) and Chamaecyparis obtusa (hinoki). The age-class distribution of artificial needle-leaved forests shown in the current Regional Forest Plan (Kagoshima Prefectural Government, 1993) is $12.3 \%$, $19.8 \%, 19.1 \%, 15.9 \%$ and $12.5 \%$ in the $16-20$ years, $21-25$ years, $26-30$ years, $31-35$ years and $36-40$ years age classes, respectively, and these age-classes represent approximately $80 \%$ of the forests. The forests in these age-classes typically require thinning. The privately owned forests are generally divided into small units with many forest owners, and the average size of holding in the study area is 0.99 ha. The average size of holding in Kyushu is 1.81ha, and the overall average for Japan is 2.69 ha.

The forest owners who replied to the questionnaire were generally quite old $; 1.5 \%$ of respondents were over 60 years old. The most important sources of income for the owners were agriculture $(33.4 \%)$, annuity $(29.6 \%)$, salary $(18.9 \%)$, and livestock (7.1\%). In this area, livestock is a major industry. In addition, $22.2 \%$ of the forest owners received income from non-wood forest products, including self-consumption. Non-wood products include fresh Shiitake mushrooms $(40.9 \%$ of forest owner with income from non-wood forest products ; plural answers), bamboo shoots $(31.8 \%)$, firewood $(16.5 \%)$, flowers $(8.5 \%)$, dried Shiitake mushrooms $(6.8 \%)$, bamboo $(6.3 \%)$, edible wild plants and medicinal herbs $(5.1 \%)$. The percentage of forest owners who had recently received income from forestry excluding non-wood products, was $13.6 \%$. Only $2.7 \%$ of forest owners had forestry as their most important income source. Thus, most forest owners in this area have small holdings and forestry is not the most important source of income in the majority of cases.

To ascertain the main reasons for owning such small holdings, the questionnaire listed ten alternatives and forest owners were asked to rank their importance over five levels. Those reasons ranked as "most important" were used as an index of the main reasons for forest ownership. The responses indicated that conservation of natural environments and water resources $(39.9 \%)$, retaining ancestral land $(30.9 \%)$, timber production $(29.0 \%)$, leaving property to descendants $(26.6 \%)$, preparation for extraordi- nary expenditure $(10.6 \%)$, benefits for local residents $(8.9 \%)$, pleasure of forestry work $(8.9 \%)$, health and pleasure for the family $(7.0 \%)$, production of by-products (3.6\%) and production of agricultural materials (3.1\%) were the major reasons for owning forest. These results indicate some important characteristics of forest ownership in this area. First, production objectives are not always very important. Most notably, the percentage of owners involved in production of non-wood products and agricultural materials was very small, less than 5\%. Previously, these activities would have been regarded as more important, but production activities are decreasing because most forest owners are aging. Their agricultural production is also small but sufficient for their own use and they have several income sources other than forestry or agriculture. Thus, the economic role of forestry for private forest owners has been decreasing. Currently, the major reasons for owning forest are related to environmental conservation and retaining ancestral lands. The latter objective is an important, traditional reason for forest ownership in Japan. Owning forest for reasons of pleasure or maintaining health is relatively recent. Managing forests as a form of insurance against unexpected expenditure has also been a traditional reason for forest ownership, but recent low timber prices have reduced the importance of this.

A typhoon damaged forests in the study area in 1993 (Matsushita, 1994). The percentages of forest owners who sustained some or extensive damage from the 13th typhoon of 1993 were $27.1 \%$ and $34.4 \%$, respectively. This damage affected not only the local forest resources but also forest management practices. Some forest owners completely lost their will to continue managing their forests. The percentage of forest owners whose forests had been damaged but who had completely finished salvaging the damaged trees by the summer of 1996, three years after the typhoon damage, was $37.6 \%$. However, $21.8 \%$ of forest owners simply left the damaged trees as they were. The existence of the typhoon-damaged forests is a serious forest issue in the region.

\section{FOREST OWNERS' CONCERNS ABOUT THE FOREST RESOURCE DATABASE}

Contents of the forest resource database

The private forest resource database, Shinrinbo, is the most important database for construction of a forest information system. The most important issue for the database is the accuracy of the contents. As previously indicated, there are many discrepancies between actual situations and the data in Shinrinbo. What do forest owners think about the differences? First, we asked whether forest owners were aware of the data registered in Shinrinbo for their own forests (see Table 2). It was found that $17.9 \%$ of 
Table 2 Awareness of the Shinrinbo

\begin{tabular}{llrr} 
& Table 2 Awareness of the Shinrinbo & (person, \%) \\
\hline Answer-1 & Answer-2 & Person & Percentage \\
\hline I am aware of the Shinrinbo. & My forests are correctly registered. & 93 & 11.7 \\
& There are some errors. & 29 & 3.7 \\
& I do not know. & 477 & 60.2 \\
I am not aware of the Shinrinbo. & I am interested in the contents. & 67 & 8.4 \\
& I am not interested in the contents. & 75 & 9.5 \\
No answer & & 52 & 6.6 \\
\hline Total & & 793 & 100.0 \\
\hline
\end{tabular}

forest owners were not aware of Shinrinbo itself. Shinrinbo is the most basic database of forest resources managed by prefectural governments, and forest owners should be aware of that. However, only $75.5 \%$ of forest owners were aware of Shinrinbo, and $60.2 \%$ of forest owners only knew of Shinrinbo by name, but did not know the contents of the database.

Only 122 persons (15.4\%) understood the contents of the database. The response "my forests are correctly registered" was selected by $11.7 \%$ of respondents, and the response "there are some errors" was selected by $3.7 \%$. Although only $3.7 \%$ of all forest owners answered that there are some errors in the database, this represented $23.8 \%$ of those forest owners who were aware of the contents of Shinrinbo. This proportion is too large. It is also worth noting that a considerable number of forest owners who indicated that they are correctly registered did not know the contents of the Shinrinbo in detail. The real ratio of forest owners whose forests were incorrectly registered is clearly greater than the response rate would indicate.

The errors that the forest owners identified in the Shinrinbo were as follows: age (12 respondents) ; area (10 respondents) ; species (9 respondents) ; and other errors (1 respondent). In total, 19 respondents identified errors. The data in Shinrinbo increases every year, and if a new plantation was correctly registered in the planting year, the age in the database should not differ from the real situation. Likewise, the species of forest does not change until the final cutting and so there should be few errors in this field of the database. However, there is more likelihood of error in area. The area of each holding in Japan is very small, and each owner may have several small forests in different locations. There were several owners who indicated the area recorded for their forest in the database was wrong, although this is difficult to evaluate. Generally in Japan, the topography and configuration of forestland is complicated, and the correct area of forestland is difficult to calculate. As the area of given unit is very small and there are many units in a forest area, survey costs are high compared to the value of the forestland and in most forest areas, surveys are not actually performed. Accordingly, almost all data on the area of forestland contains some errors.

Other errors such as age or species are easy for most forest owners to notice. Approximately one-quarter of forest owners identified errors in these fields of the database. As shown in Table 1, the Shinrinbo includes many items, which fall into three categories, namely, unchangeable data, for example, location; data that change with forest practices, for example, road conditions; and data that change annually, for example, volume. The items in the first two categories can be revised if an initial survey is correctly undertaken or data is correctly updated in response to forest practices. However, it is difficult to evaluate data that changes annually. For example, current standing volume is not easily estimated by most forest owners. In reality, there are many differences between the volume recorded in the database and the actual standing volume, but no forest owner indicated that the volume was incorrect. In the Shinrinbo, standard simple yield tables are used to automatically calculate the standing volume of each stand. Thus, the value in the database is an estimate only, not an actual measure. As the forest owner does not know the actual standing volume, he can not detect errors in the database. However, logging companies or researchers on forest mensuration can identify differences. Under these circumstances, the percentage of forest owners whose forests are incorrectly recorded in the Shinrinbo is estimated to be over $25 \%$.

Forest owners were asked when they noticed that the data recorded for their forest in the Shinrinbo was wrong. One forest owner noted errors 40 years ago. Ten out of 15 respondents stated that the errors had been found in the past ten years. However, only a few respondents indicated the year in which errors were noted and it is therefore difficult to interpret when most of the errors occurred. It is possible that the differences between data in the Shinrinbo and the real situation occurred recently. Forest owners who found erroneous data in the Shinrinbo were asked whether they contacted the administrator of the Shinrinbo. Only 4 forest owners had contacted the administrative office, and 17 forest owners had not. Twelve forest owners wanted to correct the data, but 8 forest owners did not. The exact 
reasons that most forest owners who found errors remained silent and why $40 \%$ of forest owner who found errors did not want to correct the data were not clear, but it is apparent that the existence of wrong data in the Shinrinbo does not affect the forest owner in any way.

Cooperation with the forest information system and the spread of personal computers

It was noted above that there are many discrepancies between the data in the Shinrinbo and the actual situation, but accurate forest information is necessary to properly develop a regional forest management plan. Forest owners were asked whether they were willing to supply the correct data, such as age, species and area, to prefectural governments. The response is shown in Table 3 . Only $18.4 \%$ of forest owners indicated a willingness to cooperate with such a forest information system. The other responses were split between possible cooperation under certain conditions and no interest. In this case, the data would be limited to basic information such as age, species, and area of forest, but nevertheless the percentage of respondents willing to cooperate was less than $20 \%$. Almost twice this number of forest owners were not interested in cooperating. This suggests that it would be difficult for an administrative office to obtain data from forest owners if a forest information system were started. It seemed that most forest owners thought that preparing the correct forest information for an administrative office would be similar to opening up their property. However, only basic data such as age or species was being considered, and given this, this willingness of forest owners to cooperate was low.

Forest owners were also asked whether they would cooperate with a forestry information system that required the forest owner to register data on their forest (such as age, species and area) with the local forest owners associations or regional forestry information center, and in return, receive management information, for example, recommended thinning periods. The responses are shown in Table 3. The percentage of forest owners who would like to register and obtain such information was only $10.8 \%$, almost half the percentage willing to provide correct data to prefectural government directly. These results indicated that it would be difficult for local forest owners associations to develop a new forestry information system.

To develop a new information system in the field, access to a computer would be important. According the questionnaire, $7.8 \%$ of forest owners have a personal computer. The kind of software that forest owners are using include (multiple answers, total responses from 58 persons) : word processor $(26.9 \%)$, spreadsheet (22.4), game $(19.0 \%)$, education $(19.0 \%)$, agriculture $(10.3 \%)$, communication $(10.3 \%)$, forestry $(1.7 \%)$ and other (5.2\%). A total of $20.7 \%$ of forest owners do not use their computers. Six forest owners were using the communication functions of their computers, and their ages were as follows : 50-59 years old (1 person), 60-69 years old (3 persons), and 70 years old and over ( 2 persons). Although the number is currently very small, it is interesting that some elderly forest owners are using the communication

Table 3 Registration of forest information

(person, \%)

\begin{tabular}{|c|c|c|c|}
\hline & Answer & Person & Percentage \\
\hline \multirow[t]{5}{*}{ Prefectural government*1 } & I would like to cooperate with the forest information system. & 146 & 18.4 \\
\hline & $\begin{array}{l}\text { I would like to cooperate with the forest information system depend- } \\
\text { ing on the contents. }\end{array}$ & 295 & 37.2 \\
\hline & I am not interested in the forest information system. & 277 & 34.9 \\
\hline & No answer & 75 & 9.5 \\
\hline & Total & 793 & 100.0 \\
\hline \multirow[t]{5}{*}{ Forest owners association $* 2$} & I would like to register with the forest information system. & 86 & 10.8 \\
\hline & $\begin{array}{l}\text { I would like to register with the forest information system depending } \\
\text { on the contents. }\end{array}$ & 303 & 38.2 \\
\hline & I am not interested in the forest information system. & 344 & 43.4 \\
\hline & No answer & 60 & 7.6 \\
\hline & Total & 793 & 100.0 \\
\hline
\end{tabular}

Source: Matsushita (1997) p.73

${ }^{* 1}$ Question was: It is said that there are many discrepancies between the actual forest situation and the data in the Shinrinbo. Accurate forest information is necessary to correctly develop regional forest management plans. Would you supply the correct data (age, species, areas and so on) about your own forests for the prefectural government?

${ }^{* 2}$ Question was: How do you feel about registering the forest data (age, species, area and so on) with the local forest owners association or "regional forestry information center" and obtaining management information, for example, recommended thinning periods in return. 
Table 4 Forest owner with a forest management plan

\begin{tabular}{|c|c|c|}
\hline Answer & Person*3 & Percentage ${ }^{* 4}(\%)$ \\
\hline Planned (Individual) ${ }^{* 1}$ & 75 & 10.6 \\
\hline Planned (Group) ${ }^{* 2}$ & 71 & 10.0 \\
\hline Not planned & 347 & 48.9 \\
\hline Unknown & 272 & 38.3 \\
\hline
\end{tabular}

Source: Matsushita (1997)

${ }^{* 1}$ Forest management plan based on the individual unit.

${ }^{* 2}$ Forest management plan based on a grouped forest area over than 30 ha owned by multiple forest owners.

${ }^{*}$ Multiple answers.

${ }^{* 4}$ Percentage of persons answering this question ( $=710$ persons).

function of personal computers.

Although only $7.8 \%$ of forest owners have a personal computer, the ratio is expected to exceed $10 \%$ in the near future. The total number of forest owners in the area was 19,504 in 1980 (Agriculture and Forestry Census; minimum holding of $0.1 \mathrm{ha}$ ), so it is estimated that approximately 1,500 forest owners have personal computers. A forest information system is available on personal computer in the study area.

The ownership of personal computers is also increasing among forest owners associations and logging companies. In a 1991 survey, there was only one personal computer among all the forest owners associations in the study area (excluding the department of log marketing), only four in the local forestry office of the prefectural government, and only ten in the forestry section of the municipal offices (total 18). The total number of personal computers in the forestry and forest products processing sector of the study area was 37 at the end of fiscal year 1991 , and according to the regional forestry development plan was expected to increase to 57 by fiscal year 1996 . Thus, the spread of computers within local government, forest owners associations and processing companies is much lower than among forest owners.

Private forest management plan and forest resource database

The forest planning system is part of the basic forest policy of Japan. The forest planning system has several tiers; the national level (Basic Plan on Forest Resources, Long-Term Perspective on Demand and Supply for Important Forest Products, National Forest Plan), the prefectural level (Regional Forest Plan), the municipal level (Municipal Forest Plan), and the private forest owner's level (Forest Operation Plan; hereafter, FOP). The FOP is developed by the forest owner (Individual Forest Operation Plan; hereafter, IFOP) or a group of forest owners if the total forest area is greater than a specified size (Grouped Forest Operation Plan; hereafter, GFOP). These forest plans are made cooperatively. The forest resource database for private forests, Shinrinbo, is used by prefectural governments to develop the Regional Forest Plan. In this sense, the Shinrinbo is fundamental to the Japanese forest planning system. Part of the Japanese forest resource statistics is developed from the figures in the forest planning system, so the data in Shinrinbo is very important. In the study area, the total area of non-national forest is $80,342 \mathrm{ha}$, and the total area covered by FOP was $74,464 \mathrm{ha}$ at the end of the fiscal year 1994. Thus, the percentage of forests covered by a FOP is $92.7 \%$, and almost all the private forest in the study area is covered under the forest planning system. The majority of the FOPs for the area were GFOPs $192.9 \%$ and $85.3 \%$ in the area of Ousumi and Kanoya agriculture and forestry offices, respectively.

The questionnaire asked one question about the FOP: "Have you made an FOP?" The response (Table 4) show that only $10.6 \%$ forest owner had made an IFOP and only $10.0 \%$ a GFOP. These results do not correspond with the forest plan statistics shown above. Thus, Accordingly, most forest owners who answered "no plan" $(48.9 \%)$ or "unknown" (38.3\%) have made a FOP, but they have forgotten or do not know of the existence of their FOP. The statistics for the IFOP, made by a single forest owner, were similar in the questionnaire and the official statistics on FOP. Thus, most forest owner who made an IFOP understand the existence of the plan, but in the case of a GFOP, most forest owners do not even know there is a plan.

A FOP has to be renewed every five years. In the case of an IFOP, the forest owner himself has to update the contents and file the specific application. In the case of a GFOP, the local forest owners association generally makes the plan for all forest owners who have forests in the planned area. Thus, the forest owner's involvement with the plan is much lower than in an IFOP. GFOP also have to be renewed every five years, but in most cases, the local forest owners association handles most of the procedures for renewal, further reducing the involvement of the forest 
owner and thus their memory of the plan. This is not a problem if the contents of the FOP are renewed correctly, but nevertheless the forest owner should be aware of the existence of the plan. However, in most cases, the forest owner not only has limited awareness of the FOP, but the contents of the FOP are unreliable.

\section{DISCUSSION}

Reasons for the low cooperation of forest owners with the forestry information system

The results of the questionnaire showed that forest owners' cooperation with the development of a forest resource database or forestry information system is limited. Why are forest owners not willing to cooperate with the information system using the Shinrinbo? The following three major factors were noted. (1) Forest owners do not want to provide the data. (2) Forest owners do not oppose providing forest data but they believe there are problems with the place that is to receive the data, for example, the prefectural government or local forest owners association.

(3) Forest owners are not interested in an information program if the contents are not clear to them.

Firstly, the second reason is considered. To whom are forest owners willing to provide forest resource data (assuming they are willing to provide the data)? According to the results of the survey, forest owners believes that the preferred place to manage forest resource data (age, species, area and so on) is the local forest owners association $(70.2 \%)$, the municipal offices $(9.5 \%)$, the prefectural forest owners association (3.4\%), the Forestry Agency $(2.5 \%)$, the local agriculture and forestry office of the prefectural government $(2.0 \%)$, the prefectural government $(1.0 \%)$, the district forestry office of the Forestry Agency $(0.6 \%)$ and regional forestry office of the Forestry Agency $(0.1 \%)$. Obviously, the local forest owners association was the preferred organization. Currently, the Shinrinbo is managed by the prefectural government, located at the prefectural seat. Only $3.0 \%$ of forest owners preferred the local agricultural and forestry offices or headquarters of the prefectural government. This suggests that the relationship between the forestry department of the prefectural government and forest owners is not well developed. Although municipal offices have almost no role in managing the Shinrinbo under the current system, it was the second most preferred place. It seems that forest owners want the database to be managed closer to where they live. Municipal offices are more accessible and can protect the forest owners' privacy. Under current forest resource and forestry policies, the roles of prefectural government and local forest owners associations receive considerable attention, but municipal offices generally have no specific role or budget for forestry. If the management of the forest resource database moved from the prefectural government to municipal offices or local forest owners associations, the forest owners may still not be willing to cooperate, and if they did not, the municipal office or local forest owners association do not have the authority to compel them to cooperate.

The third factor contributing to the limited cooperation by forest owners to develop a database was also important. This questionnaire did not specifically propose a new information system or changes to the policy programs in the study area. After the 1991 amendment of the Forest Law, units for forest planning were redefined, principally on the basis of major river systems. Local forestry activation centers opened and developed basic plans to activate local forestry, including developing forest resource and forestry information systems. However, in most areas, there is no defined plan to develop an information system beyond purchasing computers. Thus, forest owners have little exposure to a local forest information system. The prefectural government manages the current database, Shinrinbo, with little input from the forest owners, and most forest owners do not understand the system itself or its contents. Thus, an extension program is urgently needed to promote the value of an information system for forestry. Table 3 showed that a high percentage of forest owners would cooperate with a forest information system depending on its contents. Some of these respondents did not understand the system. For example, some forest owners may believe that he has to investigate his forest resources in detail to register his forest with a new information system, or that he has to go to the prefectural government office for registration.

The greatest difficulty facing the development of a forest information system is forest owners who do not want to provide data. This relates to the ownership of the forests and the general perception that a private forest owner has no obligation to reveal the contents of his property. This must be considered in the context of the broader forest management policies, and especially the relationship between FOPs and the forest resource data. FOPs include forest resource data such as age, species and area. If the FOP was developed using an accompanying forest inventory, the data in the Shinrinbo should be correct because the FOP is renewed every 5 years. The incentive for forest owners to make a FOP is to make them eligible for the benefits available from the government under the Forest Law. Developing a FOP includes sending correct forest data to the local government. Most forest owners have forgotten the subsidy program for forest resources, forestry and wood related industries. Subsidies are available to allow the private forest sector to manage their forest correctly despite the low price of forest products compared to labor costs and to enable forest owners to provide the non-timber values of forests that are not recognized in the 
market system. The argument for subsidies is well understood by the public, and a vanity of subsidies has been introduced to the forestry sector since World War II. Thus, private forests have not been maintained solely by the forest owner, and therefore the owners have an obligation to reveal basic forest data such as species and age.

Participation of forest owners in the forest planning system

Most forest owners do not know that their forests are registered in a database, and some forest owners are aware that incorrect data are listed for their forests but remain silent about the errors. Under the current system, there is no severe disruption of the system even if the forest owner does not participate. This has resulted in inadequate participation of forest owners in the planning system. Recently, the non-timber value of forest resources has risen, and the possibility of participation by the general public has also been discussed (e.g. Konohira (1996) and Saito (1997)). Public participation is required if the traditional forest plan that is limited to timber production is to be expanded to include other values in the future. Generally, these arguments assume that the participation of the forest owner has already been achieved for at least timber management. However, the results of this study show that the participa. tion of forest owners in forest planning is limited.

There are several problems in the forest inventory process that contributes to the development of the regional forest plan. The Japanese forest planning system has several components. The most basic plan that provides an inventory of non-national forests is the Regional Forest Plan and the FOP. Both plans are revised every five years. If accurate forest inventory data is provided at the time these plans are renewed, the discrepancies in the database should decrease. Usually, however, the figures in renewed plans are automatically revised from the data of the previous plan without an actual forest inventory. Thus, in the current system, timber volumes are estimated from the species and age of the stand with no regard to the real situation.

Without conducting an inventory, the following problems can arise during renewal. (1) The species of forest, information which forest owners can easily see incorrect, can be wrong. Generally, when a new plantation is established, the forest owner receives a subsidy from the Japanese Government. To receive this, he has to report the planting activities to the department of forestry of the prefectural government. Thus, differences between the real situation and the database do not often arise at this point. The differences arise when forest owners cut their trees without permission or reporting. As shown in Matsushita (1996a), the main problem is that there is a large proportion of cutting activities that are not reported. In most areas, greater than $50 \%$ of cutting activities are not report- ed. Reporting tends not to occur if there is potential for natural regeneration (e.g. in broad-leaved trees) or if the cutting area is small or selective cutting was used. (2) The volume listed in the database does not always approximate the real situation. The stand volume in the database is estimated automatically from the recorded species, age and site-class using the yield table in the computer. Even if the yield table is correct, the volume will not be correct if the site-class of the forest stand has not been correctly evaluated. In Kagoshima Prefecture, all forests in a sub-compartment are given the same site-class designation for convenience (YoshidA, 1997). This can clearly cause errors in the database. In addition, the yield tables used by most Prefectural Governments were calculated in the 1950s and 1960s. In Kagoshima Prefecture, it is not clear when and how the yield tables were estimated, but the yield tables have been used by the prefecture since before 1970 (YoshiDA, 1997). Thus, the yield tables themselves may also be incorrect or inappropriate.

It is clear that neither the forest owner nor the forestry department of prefectural government has an adequate understanding of forest inventory and nobody knows the true status of the forests. Both forest owners and forest technicians must know that the figures in the database are inaccurate because they are calculated automatically and not checked by surveys. This removes forest owners from any involvement in the construction of the forest resource database. If the forest owner is dependent on income from his forest, he must do his own inventories. However, most forest owners cannot complete a forest inventory over a wide area on their own, and they depend on the public sector. In Kamiyahagi, Gifu Prefecture, the municipal office and regional forest owners association cooperated between 1977 and 1978 to improve the accuracy of the Shinrinbo (Iто et al., 1983). The prefectural government first sorted the database by forest owner and combined the new database with the plan of forestry activities (cutting, planting and thinning) to create a Forest Management Register. This register was made available to the 900 forest owners of the town, and was checked by completing an inventory and confirming each owner's planned activities over the next five years. The resulting Forest Management Register was distributed to each forest owner, and each began to use the accurate forest database. This contrasts with the situation in the present study in which most forest owners do not know how their forests are listed in the official database. The Register in Kamiyahagi was an effective use of the subsidy for promotion of regional forestry. The Shinrinbo is the most basic database for both timber production and management of non-timber values. Only about $10 \%$ of forest owners develop an IFOP, as most forest owner's holdings are too small for an effective IFOP. Stumpage prices have been decreasing in Japan and as a result, most forest owners do not expect as high an eco- 
nomic return as they received previously. In this situation, it is difficult to expect participation by forest owners in forest inventory. Therefore, cooperation of the public sector (e.g. municipal offices and forest owners associations) is important.

KUMAZAKI (1997) proposed a cooperative national forest inventory to be done by the Forestry Agency, Environment Agency, prefectural governments, municipal offices, and volunteer citizens. If forest owners abandon forest inventory, such a national forest inventory will be essential, what are the implications of doing inventories without the participation of the forest owner? This proposal seems to place a low value on the contribution of forest owner, but without it, there will clearly be problems, as shown in the study. The cooperation of forest owners is thus very important. The first step in attracting the participation of private forest owners in the forest planning process seems to be to involve them in data collection.

\section{CONCLUSION}

Since the Shinrinbo has many problems, it is not greatly utilized, improvement of the Shinrinbo must be accompanied by improved utilization. Generally, the current forest statistics system in Japan was developed in the latter half of 1940's and has remained almost unchanged since (Management and Coordination Agency, 1995). The Shinrinbo system was created for use by the prefectural government and Forestry Agency. Their main purposes have been to obtain basic data to develop forest plans and to report regional or national forest resource statistics over a long time. The Shinrinbo has been used for this despite the discrepancies in the data. The potential uses of the Shinrinbo have changed, because there are now greater expectations on how forests are managed with more public interest in non-timber values. There is a general lack of statistics on environmental resources in Japan and the forest resource database must be improved and expanded to satisfy users with environmental interests. Use of the Shinrinbo has traditionally been limited to administrative functions within the prefectural and national forestry departments. Discrepancies in the data will become an even greater problem when use of the database expands beyond these areas. Therefore, a number of policy changes are required to reorganize the Shinrinbo and improve its utility.

First, the contents of the current database have to be distributed to all forest owners with a questionnaire which would allow discrepancies in the data to be identified. This would allow forest owners be become familiar with both the system and the contents of the database. After distributing the questionnaire, a forest inventory would be required to check the data. This should be done by the department of forestry of prefectural governments and local forest owners association in cooperation with the forest owners. Retired foresters, foresters from the National Forests, foresters from public forests (prefectural forests and municipal forests), foresters from university forests, as well as teachers and students from the department of forestry at universities could participate. Any other people interested in forest inventory would also be welcome to participate. A national inventory would be ideal, but the cost would be high. As a minimum, surveys should be conducted within each forest planning area, and they could be conducted over several years. Some kind of subsidy may be required to facilitate these surveys.

There are also problems, related to the forest planning system under the current Forest Law. Currently the forest inventory described above must be updated when the FOP is revised every five years. The total area covered by a FOP has been increasing, but the accuracy of the database has been deteriorating. The method of renewing this five-year plan must be reviewed. Why do prefectural governments authorize plans that are not based on a survey? As it would be difficult for both forest owners and the forest administration to repeatedly perform a forest inventory every year or even periodically, an initial survey and periodic partial review should be done. Most forest owners make a FOP, and this system has to be improved, particularly for GFOPs, but most owners are not aware of the FOP renewal procedure. The connection between Shinrinbo and the FOP for forest planning must also be considered. KonDo (1993) noted the important role of the "Forest Resources Conditions and Cutting \& Planting Plan" that is included in the FOP. In Kondo's study, the data was not linked to the master file on forest resources, which was closely linked to the Shinrinbo. In this study area in Kagoshima Prefecture, records in the Shinrinbo have occasionally been corrected using data from FOPs in the local forest owners association. However, the number of cases is very limited, and such links are now exceptional. Statistical and administration systems must share information, but the access to information must give consideration to the protection of privacy.

A policy must also be developed to cope with forest owners who are indifferent to their forests or who do not live in the village where their forest is located. Those owners interested in forest management, expecting income from forestry or with a connection to their forest will probably be involved in the forest inventory and will contribute to improving the forest planning system. However, if the forest owner is not interested in his forest, the forest administration sector must still obtain the correct data about his forest. The recent increase in local forest owners associations managing forests is expected to continue (Matsushita, 1998). As the number of forest owners who do not know even the location of their forests increases. Thus, some kind of consulting system will also need to be 
introduced.

The utilization of Shinrinbo must also be promoted. The current database contains many errors and its use is limited. Improvement of contents and increasing its use should be done together. The current policy for promoting forestry recommends introducing local forest information systems. Similar data as that in the Shinrinbo will be required in local systems, and it would be logical to link the two systems. Greater use of the Shinrinbo for research would also improve its accuracy. If there is to be greater use of the Shinrinbo, new systems of protecting privacy will need to be developed. These may include limiting access to the data to specific levels, such as $10 \%$ or $20 \%$, or to specific types of data, such as time-series-data (when to cut, when to plant, and so on) which can be used for economic analysis.

\section{ACKNOWLEDGEMENT}

I would like to thank Kagoshima Prefecture Forest Owners Association for conducting the survey and the forest owners who responded. The questionnaire was carried out as part of the labor conditions survey project in fiscal year 1996. This research was funded by the Grant-in -Aid for Scientific Research on Priority Areas of the Ministry of Education, Science and Culture of the Government of Japan (fiscal year 1996, research number 08209112, subject: an analysis on the effective utilization of microdata on private forest ; fiscal year 1997, research number 09206207, subject:an analysis of effective utilization of micro-data on non-national forest).

\section{LITERATURE CITED}

Ito, M., Kanou, H. and Fujisawa, S., (1983): The method of utilization and improvement of accuracy of Shinrinbo* Kaihou 278/279:45-50 (in Japanese)

Kagoshima Prefectural Government, (1993): Regional forest plan of Ousumi Forest Planning Area*, planning period: from April 1 of 1993 to March 31 of 2003. Kagoshima, 189pp (in Japanese)

KoIKE, K. and FuJISAKI, N., (ed.) (1997): Forest resource accounting Experience in North Europe and trials in Asia -. Institute of Devel. oping Economies, Tokyo, 347pp (in Japanese)

КомакI, T., (1988): Shinrinbo management system by computer*. Hoppou Ringyo 40 (11): 5-7 (in Japanese)

КоNDOH, H., (1993): Present situation and problems of forest information - A case study on a forest owner's association -. Trans. Jpn. For. Soc. $104: 227-228$ (in Japanese)

KonohiRA, Y., (1996): Manual of forest environment conservation*. Asakura-shoten, Tokyo, 183pp (in Japanese)

Kumazaki, M., (1997): The future of Japanese private forestry - How to make use of man-made forests of ten million hectares -. Forest Economics $586: 17-28$ (in Japanese)

MaKINO, Y. and HASHIMOTo, A., (1994): Outline of geographical information system, usable for introducing high efficient forestry machines.
Journal of the forestry mechanization society $486: 19-22$ (in Japanese)

Management and Coordination Agency, Statistics Bureau (1995): New long-term plan on the administration of statistics. Report of Statistical Administration Council, Zenkoku-Toukei-Kyoukai-Rengoukai, Tokyo, 204pp (in Japanese)

Matsushita, K., (1995): Forest damages by the 13th typhoon in 1993 and forest insurance contracts in Kagoshima Prefecture. Bull. Kagoshima Univ. Forests $23: 81-99$

MATSUSHITA, K., (1996a): An analysis of the recent situation and problems in the cutting reporting system. J. For. Plann. 2:67-75

MAtsushrta, K., (1996b): Report on forestry workers conditions in Kagoshima Prefecture. Hokusatsu Forest Planning Area, Kagoshima Prefecture Forest Owners Association, Kagoshima, 87pp (in Japanese)

Matsushita, K., (1997a): A study on the effective utilization on microdata of private forests (in MATsUDA, Y., (ed.): Exploring new frontiers in statistical analysis using micro data sets). Hitotsubashi University, Tokyo, 98-110

Matsushita, K., (1997b): Report on forestry workers conditions in Kagoshima Prefecture. Ousumi Forest Planning Area, Kagoshima Prefecture Forest Owners Association, Kagoshima, 82pp (in Japanese)

MAtsushita, K., (1998): Forest management by local forest owners association. Bull. Kyoto Univ. Forests $69: 54-67$ (in Japanese with English Summary)

NishiKaWA, K., (1994): Trends and prospects of national forest inventories of the advanced nations - toward multi-resources inventories -. Jpn. J. For. Plann. 22 : 1-18 (in Japanese with English Summary) Ousumi Forestry Activation Center, (1993): The basic activation plan of Ousumi forestry*. Kanoya, 57pp (in Japanese)

SArro, K., (1997): A review of "participation" in forest management (I) about issues under discussion on public participation in forest planning process. Jpn. J. For. Plann. 28 : 1-6 (in Japanese)

Shinkin KeiKaku Seido Kenkyukal, (1992): Administrative work on forest planning*. new-ed., Chikyu-sha, Tokyo, 574pp (in Japanese)

SHIRAISHI, N., (1995): Pursuing a better forest inventory data management system, From the next-stage forest inventory system development survey reports. Jpn. J. For. Plann. 25 : 83-95 (in Japanese)

TAtsuhara, S., (1994): Predicting growth of coniferous plantations with stand table, Trans. Jpn. For. Soc. $105: 175-176$ (in Japanese)

Yамамото, N., (1997): Toward a construction of consistent forest sector statistics. Forest Economy 581:5-13 (in Japanese)

Yonemoto, N. and HiraI, M., (1994) : Development of GIS in the conception of information programs in department of forest policy of Gifu Prefecture*. Kaihou $362: 27-42$ (in Japanese)

YoshiDA, M., (1986): Data renewal of Shinrinbo using personal computer*. Kaihou $297: 19-26$ (in Japanese)

YoshidA, S., (1997): The recent situation and problems of forest inventory* (in MATsushita, K., (ed.): A study on the effective utilization of micro-data on private forests), Kyoto University, Kyoto, 41-55, 76 -77 (in Japanese with English Summary)

*The titles are tentative translations from original Japanese titles by the authors of this paper.

(Received 29 September 1997) (Accepted 16 April 1998) 